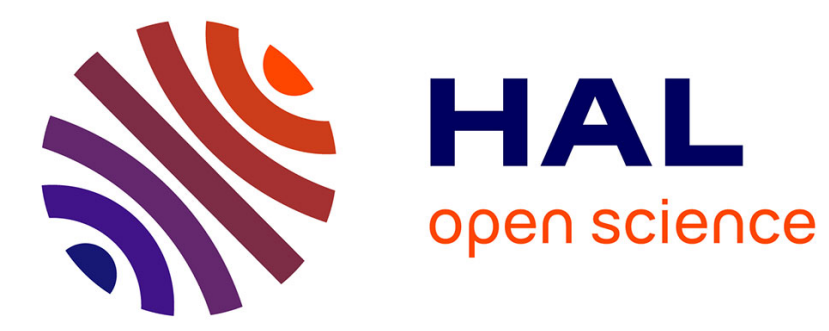

\title{
Physical and mechanical properties of reaction wood
}

Bruno Clair, Bernard Thibaut

\section{To cite this version:}

Bruno Clair, Bernard Thibaut. Physical and mechanical properties of reaction wood. The biology of reaction wood, Springer-Verlag Berlin Heidelberg, 249 p., 2014, Springer Series in Wood Science, 978-3-642-10813-6. 10.1007/978-3-642-10814-3_6 . hal-01135273

\section{HAL Id: hal-01135273 \\ https://hal.science/hal-01135273}

Submitted on 1 Dec 2021

HAL is a multi-disciplinary open access archive for the deposit and dissemination of scientific research documents, whether they are published or not. The documents may come from teaching and research institutions in France or abroad, or from public or private research centers.
L'archive ouverte pluridisciplinaire $\mathbf{H A L}$, est destinée au dépôt et à la diffusion de documents scientifiques de niveau recherche, publiés ou non, émanant des établissements d'enseignement et de recherche français ou étrangers, des laboratoires publics ou privés.

\section{다)(1) $(5$}

Distributed under a Creative Commons Attribution - NonCommercial| 4.0 International 


\title{
Physical and Mechanical Properties of Reaction Wood
}

\author{
Bruno Clair and Bernard Thibaut
}

\begin{abstract}
Reaction wood produces very peculiar maturation stresses at the tree periphery, i.e. compressive stress or very high tensile stress, for compression and tension wood, respectively, as compared to moderately high tensile stress for normal wood. This means that both its mechanical state and its mechanical and physical properties differ from normal wood.

Compression wood shows big differences from normal wood in conifers, for all physical and mechanical properties: higher density and axial crushing strength (MOR) but lower modulus of elasticity (MOE), far higher axial (longitudinal) shrinkage but lower radial and tangential shrinkage, sometimes even lower than the axial shrinkage.

For tension wood things are less simple and can vary a lot from hardwood species to species. Globally there are no systematic differences in density and transverse shrinkage; MOE tends to be a little higher while MOR is slightly lower. However, axial shrinkage is much higher for tension wood with a gelatinous layer (G layer) than normal wood due to the specific gel-like organization of matrix in the G layer. For tension wood without a $\mathrm{G}$ layer (which is rather frequent) axial shrinkage is around two times higher than in normal wood. This paradoxical shrinkage is thought to originate from the release of maturation stresses during drying.

Overall the very high tensile stress and stored elastic energy in tension wood lead to problems in wood processing (end splitting and board warping), which is far less the case for compression wood. But due to the large difference in properties relative
\end{abstract}

\author{
B. Clair $(\square)$ \\ CNRS, UMR Ecologie des Forêts de Guyane (EcoFoG), Campus Agronomique, BP 701, \\ 97387, Kourou, French Guiana, France \\ Laboratoire de Mécanique et Génie Civil (LMGC), CNRS, Université Montpellier 2, \\ Place E. Bataillon, CC048, 34095 Montpellier Cedex 5, France \\ e-mail: bruno.clair@univ-montp2.fr \\ B. Thibaut \\ Laboratoire de Mécanique et Génie Civil (LMGC), CNRS, Université Montpellier 2, \\ Place E. Bataillon, CC048, 34095 Montpellier Cedex 5, France
}


to normal wood, compression wood occurrence is always a big problem for the in service behaviour of timber, which is seldom the case for tension wood.

\subsection{Introduction}

The technological properties of reaction wood (RW) have been extensively studied because they generally reduce the quality of wood products and therefore have important commercial consequences. The presence of reaction wood may affect timber at two levels: firstly at the tree or plank level when distortion arises as the heterogeneous stress field across the wood is modified by crosscutting and sawing. This manifests itself when the tree is felled as log-end cracks or later during sawing as distortion and cracks in the wood. The presence of reaction wood at the periphery of the stem tends to increase the stress gradient in the case of tension wood (TW) and decrease it in the case of compression wood (CW). It results, in some cases, an increase in log-end cracks when TW, but not when compression wood is present (Jullien and Gril 2003).

The second effect of reaction wood on wood products is linked to the differences in its structure and chemical composition compared with those of normal wood (NW) (see Chaps. 2 and 3). These differences affect its density, its mechanical behaviour, its behaviour with moisture change, and other properties such as colour and texture.

This chapter will focus on the properties of reaction wood as material, including the effect of the release of stress, but not the structural effects linked to heterogeneity in the tree. The latter will be discussed in detail in Chaps. 8 and 9.

\subsection{Density}

Density has long been understood to be the main factor affecting the mechanical properties of wood. Simply speaking, the denser the wood the stronger and stiffer it is. When properties are compared between species, this factor is of primary importance compared to other structural parameters such as microfibril angle (MFA), which is the second most influential parameter, or chemical composition. Thus, because of density differences related to species, oak (Quercus spp.) will always be stiffer than poplar (Populus spp.) whatever the MFA. Density is also linked to physical properties such as swelling and shrinkage of wood, although the relationship is not as direct as in the case of strength properties. Furthermore, density is the easiest parameter to measure in wood, so it is generally used to estimate its quality and potential uses.

However, although density is the first order factor affecting properties when comparing species or trees, the relationship becomes less clear when comparing properties in a single tree and especially when studying reaction wood, where structural changes become of greater importance in influencing wood behaviour. 
Thus, compression wood, although denser than normal wood, is less stiff. In hardwoods, the relationship between density and stiffness is also disturbed, with large changes in stiffness occurring without concomitant changes in density. ${ }^{1}$

It is important not to confuse wood density and cell wall density. The term wood density refers to macroscopic measurement, and depends on the amount of cell wall compared to void volume (fibre and vessel lumina, for example) and can thus show considerable variation from species to species, whereas the term cell wall density refers to the cell wall itself and thus depends only on the chemical composition of the cell wall. Cell wall density is very stable among species.

\subsubsection{Density of Compression Wood}

Compression wood is almost always denser than normal wood. Timell (1986) cites numerous publications which all confirm this tendency. In more than $75 \%$ of the studies described by Timell, a ratio of density of $\mathrm{CW} / \mathrm{NW}$ of 1.1-1.8 was found with some extreme cases showing up to 2.2 . In $16 \%$ of the studies, the ratio was between 1 and 1.1. These rarer cases he attributes to the accidental inclusion of compression wood in the normal wood sample.

The specific gravity of the cell wall in compression wood can be computed assuming the densities of lignin, cellulose, and hemicellulose, respectively, as 1.4, 1.58 , and 1.50. Since compression wood is richer in lignin (around $40 \%$ ) than normal wood (around $30 \%$ ), cell wall density is lower in compression wood than normal wood (respectively, around 1.48 and $1.50 \mathrm{~g} \mathrm{~cm}^{-3}$ ). The high increase in macroscopic density is linked to the fact that the cell wall is much thicker in compression wood than in normal wood. This agrees with another observation by Timell (1986) that the ratio in density is even higher in species where normal wood is less dense.

\subsubsection{Density of Tension Wood}

General trends are more difficult to find in tension wood since it is much more variable than compression wood in terms of structure and occurrence. Several studies have compared tension wood and normal wood without considering the severity of the tension wood and found that tension wood has a higher density than normal wood (Chow 1946, 1956; Arganbright et al. 1970; Jourez et al. 2001a;

\footnotetext{
${ }^{1}$ Density is defined as the ratio between the mass of a material and its volume. For wood, it has been traditional to use what is called basic density, which is the ratio between oven-dry mass and saturated volume. The latter measurement is chosen because it is easy to determine in practice, since volume measurement is generally made by immersing the wood in water and applying Archimedes' principle. The comparison in density between normal wood and reaction wood is, however, little affected by the definition used.
} 
Coutand et al. 2004). Lowell and Krahmer (1993) observed no significant effect of leaning of tree on wood density. Ruelle et al. (2007a) studying ten tropical species reported that three of them showed no significant difference in density between normal wood and tension wood while in the five trees that showed a significant difference, two had a lower density in tension wood. However the differences were small except in the case of Virola surinamensis (Rolander) Warb. where density was lower in tension wood, and Qualea rosea and Ocotea guyanensis where density was higher in tension wood. Similarly, McLean et al. (2012) found on six tropical species only $O$. guyanensis with tension wood significantly denser than opposite wood, whereas on three of them (Sextonia rubra, Virola michelii, Tachigali melinoni) the trend was reversed and no trend was found for the two other species.

Some other studies measured the change in density for a gradual change in severity of tension wood. Severity was expressed as the percentage of gelatinous layers in the wall (which is of course only applicable to species which have a G-layer) or was measured using release growth-strain measurement. Where the amount of G-layer was measured, a positive correlation was sometimes found between density and tension wood fibre percentage (Kroll et al. 1992; Washusen et al. 2001; Clair et al. 2003c) although Arganbright et al. (1970) showed no correlation between density and percentage of gelatinous fibres. When density was related to growth-strain measurements, no general tendency was found. Fang et al. (2008a) showed a significant but weak positive correlation in poplar, as did Yang and Ilic (2003) in Eucalypts globulus Labill. Boyd (1980) showed a significant positive within-tree relationship between growth strain and density in 10 of 17 trees (16 Eucalyptus regnans and one Eucalyptus obliqua) studied (mostly the trees undergoing crown-reorientation), but no significant among-tree relationships were found between growth strain and density. Chafe (1990) found a highly significant positive relationship between growth strain and density for E. regnans, but not for E. nitens. Baillères (1994) found no relationship between density and residual maturation strain when all tree ages were considered but showed that the relationships became significant when analysis was done intra-tree for young trees. In older trees, density reached a maximum and the presence of tension wood did not increase it significantly.

The high variability described above results from more complex factors affecting density in hardwoods. Because angiosperms have specialized tissues, the density does not depend only on cell wall thickness as in compression wood tracheids, but also on the proportion of tissues and especially the number and size of vessels. Numerous studies have found that there is a lower proportion of vessels having a smaller diameter in tension wood (Jourez et al. 2001b on poplar; Ruelle et al. 2006 on 21 tropical species). Density is also affected by wall thickness, which is generally assumed to be greater in tension wood with gelatinous fibres. Despite the probability that most studies have overestimated this measurement since the G-layer appears in a swollen state in microscope sections (Clair et al. 2005c), a recent study on poplar showed that G-fibres have a thicker wall than normal fibres where they have not been affected by sectioning (Fang et al. 2007, 2008b). When growth stresses increase, an increase in G-layer thickness is observed but 
compensated for by a decrease in thickness of the $S_{2}$ layer so that the wall thickness of G-fibres is similar to that of normal fibres in poplar (Fang et al. 2007). For species without a G-layer, fibre wall thickness is sometimes significantly thinner in tension wood (Ruelle et al. 2006) and could explain observations of lower density of tension wood in some species.

Following the same reasoning as for compression wood, the density of the cell wall in tension wood can be estimated. Whether or not a G-layer is present, tension wood is always reported to be less rich in lignin and more rich in cellulose than normal wood. Cell wall density would therefore be higher than in normal wood. However, in the peculiar case of the gelatinous layer, even if it is known that lignin is essentially absent, its density is probably not higher than the lignified wall. In fact, the high transverse shrinkage around $20 \%$ (Fang et al. 2007) during drying is a proof of its high water content. Allowing for a $20 \%$ void in the G-layer its density can be estimated at about $1.25-1.27 \mathrm{~g} \mathrm{~cm}^{-1}$, much lower than that of the normal wood or compression wood cell wall. This low density is linked directly to its high mesoporosity (pore size around 6-10 $\mathrm{nm}$ ) as observed in chestnut (Castanea sativa) or louro vermelho (S. rubra) (Clair et al. 2008; Chang et al. 2009a). This low density contributes to confusion about the relationship between wood density and tension wood since the amount of G-layer increases with increasing growth stresses (Fang et al. 2008b).

\subsection{Mechanical Behaviour of Reaction Wood}

An analysis of the literature shows that there are three main groups of workers interested in the mechanical behaviour of reaction wood. The larger group is made up of wood scientists who study wood as a raw material for commercial use. This means that they study wood properties in the conditions of use, i.e. dry, below the fibre saturation point. The other group comprises scientists working in the field of biomechanics who study wood in order to understand its function in tree. In this work, experiments are mainly carried out on wood in the green or wet state. A third group of workers study the change in the properties of the wood during drying to obtain information about the origin of the properties of reaction wood (Clair et al. 2003c, 2006a; Yamamoto et al. 2009).

As discussed it in the previous chapter, mechanical behaviour is largely affected by density. In order to identify the contribution of density to wood properties, mechanical properties such as modulus of elasticity (MOE) or strength can be expressed by their specific modulus or specific strength by dividing the studied properties by the density of the samples. This makes it possible to identify the contribution of ultrastructure to the particular property. 
Fig. 6.1 Relationship between MFA and longitudinal modulus of elasticity (MOE) and relationship between MOE and density/MFA for three eucalyptus species between 15 and 33 years of age (from Yang and Evans 2003)
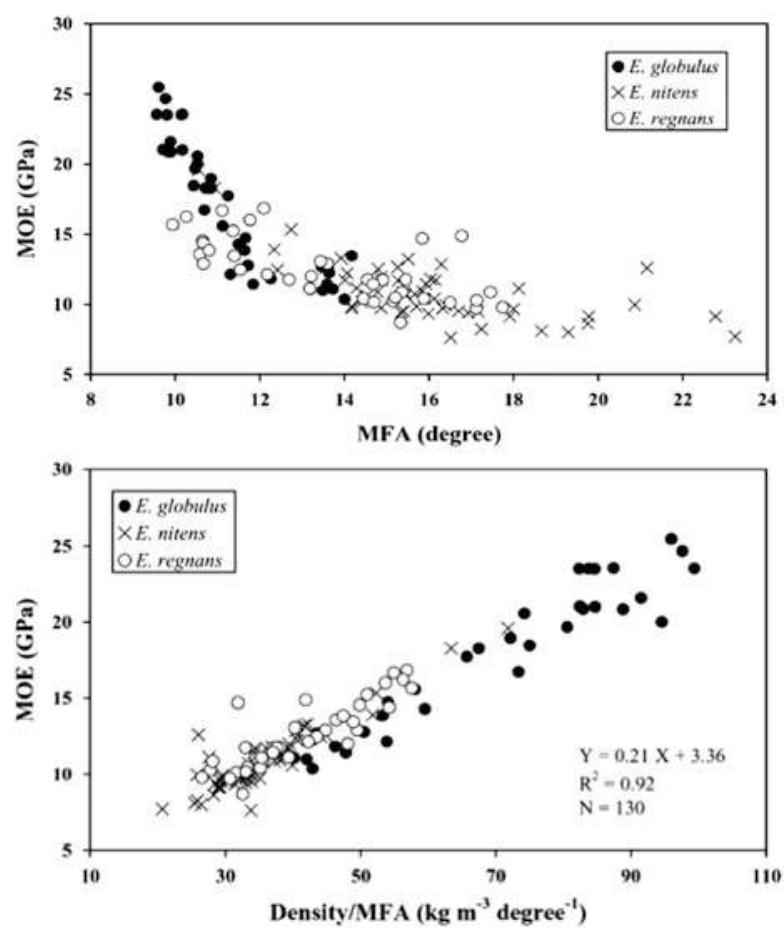

\subsubsection{Visco-Elastic Properties}

\subsubsection{Longitudinal}

Properties at the Macroscopic Level

Numerous investigations, both from measurement and modelling, have shown that there is a good relationship between elastic properties in the longitudinal direction and MFA in the secondary wall (Fig. 6.1) (Cave 1969; Mark 1973; Salmén and Ruvo 1985; Koponen et al. 1989, 1991; Astley et al. 1998; Harrington et al. 1998; Reiterer et al. 1999; Salmén 2004). Recent research has become more focused on second-order properties arising from properties and organization of other cell wall components (Salmén and Burgert 2009). Reaction wood is known to be characterized by a great change in MFA, which is higher than in normal wood in compression wood and lower in tension wood. Thus, during a test along the longitudinal direction, load will be applied essentially on the microfibrils rather than the matrix in tension wood. The matrix will be more affected when the MFA increases as in compression wood. As cellulose microfibrils are much stiffer than the matrix materials, the stiffness will be higher when MFA is low, as in tension wood and lower in compression wood where the MFA is large. A concomitant parameter is 
Fig. 6.2 Relationship between $E^{\prime} / \rho$ and $\tan \delta$ measured on strips; filled symbols: compression wood; open symbols: normal wood; triangle: spruce; square: maritime pine; rhombus: Scots pine (from Brémaud et al. 2013, Ono and Norimoto 1983)

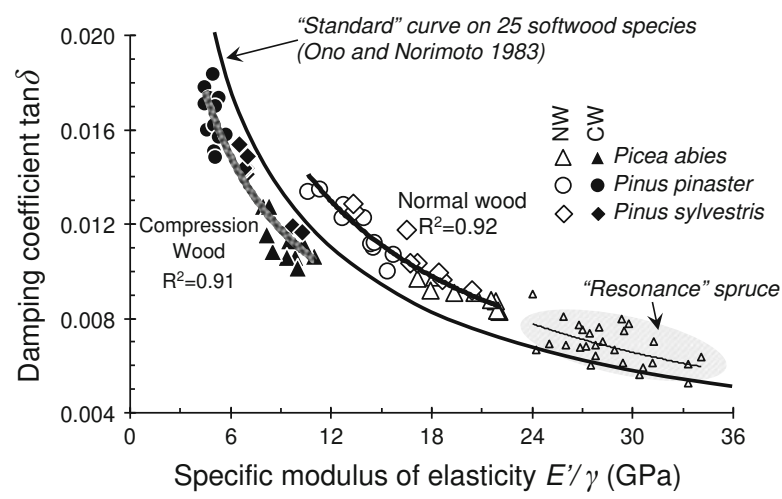

the amount of matrix compared to cellulose. Compression wood is known to be more lignified and contain less cellulose compared to normal wood and tension wood to be more cellulosic. This characteristic is directly related to the difference in reaction wood properties, but as shown by Gindl (2002) the effect of increased lignin content on the Young's modulus in compression wood is generally not discernible because of the dominating influence of MFA. However, concerning visco-elasticity, it has been shown that the changes in MFA cannot explain the complementary reduction in acoustical damping found in compression wood as compared to normal wood (Fig. 6.2) (Brémaud et al. 2013).

All investigators agree that the MOE of compression wood is much lower than that of either opposite or normal wood. This finding does not depend on the nature of the force applied, whether compression, tension, or static bending (Timell 1986), and agrees well with expectations based on the fact that the MFA in compression wood is large compared to that in normal wood (Reiterer et al. 1999). For example, Burgert and Jungnikl (2004) using wet thin strips of spruce wood found values of around 1,000 MPa for compression wood, 3,250 MPa for opposite wood, and an intermediary value of 1,750 MPa for lateral wood [and, respectively, around 2,000, 3,000, and 2,500 in Yew (Taxus spp.)]. They confirmed the relationship with MFA but were unable to find a relationship with density. Timell (1986) reported that the increase of MOE is modest after drying, and is the same for compression wood as for normal wood.

The situation with regard to the elastic behaviour of tension wood is less clearcut than for compression wood. Because the MFA in tension wood is always lower than that in normal wood (Clair et al. 2006b), modelling would predict an increase in stiffness. However, studies have produced contradictory results even within a genus. For example, in poplar, some authors found tension wood to be much stiffer than normal wood (Fang et al. 2008a) up to two to three times (Coutand et al. 2004; Dinh et al. 2008 using three and four points bending, respectively), whereas in another study it was found that the difference was significant in only one of the three hybrids studied (Alméras et al. 2005 using the dynamic flexion test). Boyd (1980) using tensile testing compared MOE to growth strain measured in the tree 
and found a significant positive within-tree relationships in only 9 of 17 eucalyptus trees studied (mostly trees actively reorientating their crowns) but no significant among-tree relationship between growth strain and MOE. Similarly, Baillères (1994) reported a poor relationship between MOE and growth strain when all trees were taken into account but noticed that the relationship became significant within each tree.

Chafe (1990) found that even within the tree no relationships were noticeable. The same observation was made by Yang and Ilic (2003) who reported that, unexpectedly, some of the specimens that had marked tension wood with high density and thick cell walls had lower MOE values than other normal wood specimens. This work was carried out using wet wood samples. Similarly, Clair et al. (2003c) observed a higher dispersion of MOE in chestnut tension wood than in normal wood, indicating that some tension wood samples have a higher MOE and some a lower MOE compared to normal wood. Yamamoto et al. (2009) showed that when comparing the relationship of growth strain and MOE of oak wood (Quercus acutissima) the difference was small in the wet state and became greater in dry wood.

Ruelle et al. (2007a, 2011), Alméras et al. (2005), and McLean et al. (2012) reported that in most species, tension wood is stiffer than normal wood. Ruelle et al. (2007a) studied ten tropical species and found that longitudinal MOE and specific MOE in the dry condition were higher in tension wood of eight trees (between 16 and $54 \%$ higher, as specific MOE), except in Cecropia sciadophylla Mart. and $V$. surinamensis (Rolander) Warb in which specific MOE was very high both in tension and in opposite wood (the difference was statistically significant for seven trees). Alméras et al. (2005), working on 11 tropical species and 3 poplar hybrids (wet wood) noticed that trees with the highest MOE for normal wood had higher MOE for tension wood, whereas most of the trees with low MOE (Populus I-MC, Populus I-214, Jacaranda copaia, Simarouba amara) had similar MOE values for normal and tension wood. Among trees where differences were significant, five had a higher MOE for tension wood than for normal wood and 2 had a lower MOE in tension wood (Fig. 6.3).

Concerning the viscosity of tension wood along the fibres, McLean et al. (2012) reported a higher damping in wet tension wood compared to normal wood only in species producing a G-layer, whereas for non-G-layer tension wood the difference in $\tan \delta$ was non-significant or reversed. After drying the difference remained significant only for two of the three G-layer producing species.

\section{Properties at the Fibre and Cell Wall Level}

Burgert et al. (2002, 2003, 2005a, b) carried out several studies comparing the properties of isolated fibres. Compression wood always had a much lower MOE compared to other studied wood types (Fig. 6.4). When comparing compression wood from different species Burgert et al. (2004) found that elastic behaviour differed more significantly at the tissue than at the fibre level, raising questions about the contribution of fibre arrangement to wood behaviour. 


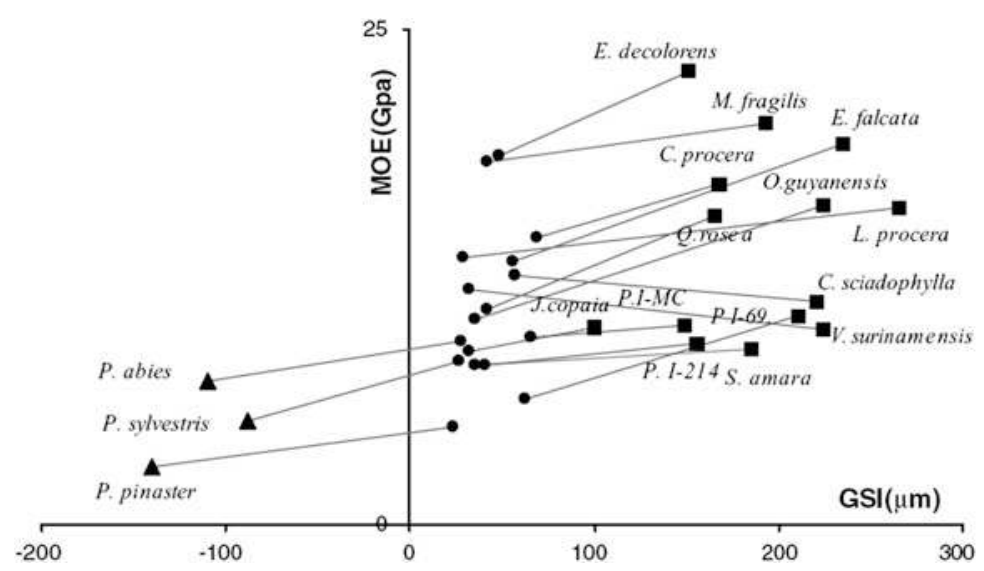

Fig. 6.3 Modulus of elasticity of reaction wood and normal wood versus growth strain indicator for 17 trees. Triangles: compression wood, circles: normal wood, squares: tension wood. Lines join the normal and reaction wood from the same tree (from Alméras et al. 2005)

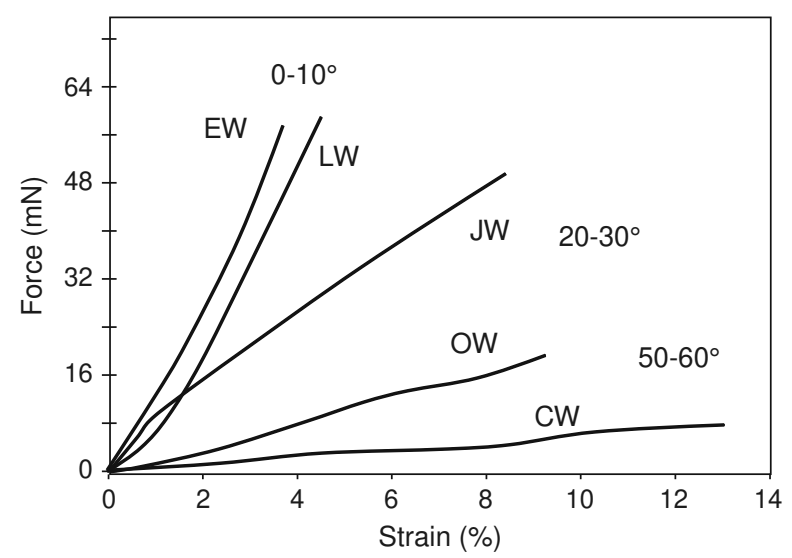

Fig. 6.4 Load strain diagram of mechanically isolated fibres. $E W$ early wood, $L W$ latewood, $J W$ juvenile wood, $O W$ opposite wood, $C W$ compression wood. Corresponding range of MFA is given for each group of wood type (from Burgert et al. 2002)

Clair et al. (2003c) and Yamamoto et al. $(2005,2009)$ investigated the contribution of the gelatinous layer to the MOE. The first of these studies was performed on chestnut wood and showed a significant correlation between longitudinal Young's modulus and the percentage of fibres with a G-layer (G-fibres) both in the wet and dry condition, irrespective of the thickness of the G-layer. Similar results were found for maple (Acer spp.) wood (Yamamoto et al. 2005). Later, Yamamoto et al. carried out a similar study on kunugi oak wood ( $Q$. acutissima) and found an even better correlation when they considered the area ratio of G-layer 
Fig. 6.5 Mean ratio and standard deviation of modulus of elasticity from wet to dry as a function of the proportion of G-fibres in the samples. Numbers indicate the number of specimen for each class (from Clair 2001)

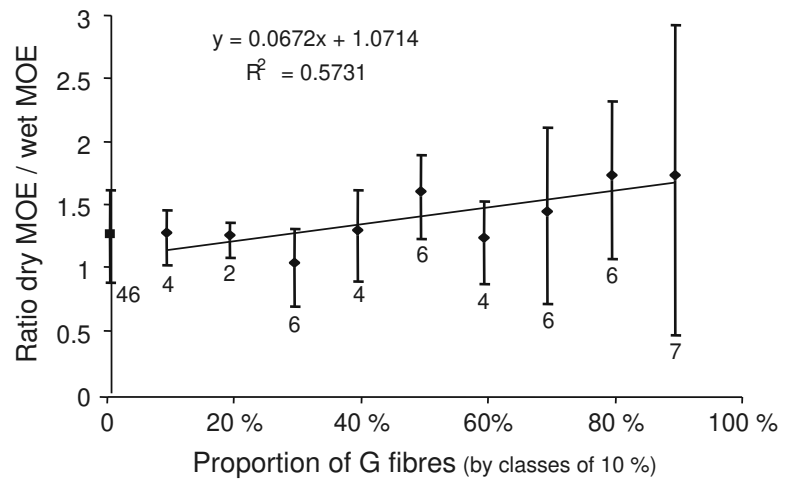

Table 6.1 Modulus of elasticity of G-fibres and non-G-fibres and for G-layers and other layers computed from a mixture model (Chestnut data: Clair et al. 2003c; Maple data: Yamamoto et al. 2005; Oak data: Yamamoto et al. 2009)

\begin{tabular}{lclc}
\hline & Wet MOE (GPa) & Dry MOE (GPa) & Increase during drying \\
\hline Non-G-fibres (chestnut) & 14.5 & 15.1 (air-dry) & $4.14 \%$ \\
G-fibres (chestnut) & 21.6 & 31.3 (air-dry) & $44.91 \%$ \\
Non-G-fibres (maple) & 8.50 & & \\
G-fibres (maple) & 16.24 & & \\
Cell wall in non-G-fibre (maple) & 13.13 & & \\
Non-G-layer in G-fibre (maple) & 16.28 & & \\
G-layer in G-fibre (maple) & 28.27 & 17.70 (oven-dry) & $19.68 \%$ \\
Non-G-fibres (oak tree 1) & 14.79 & 39.16 (oven-dry) & $145.06 \%$ \\
G-fibres (oak tree 1) & 15.98 & 29.52 (oven-dry) & $29.53 \%$ \\
Non-G-fibres (oak tree 2) & 22.79 & 41.64 (oven-dry) & $66.43 \%$ \\
G-fibres (oak tree 2) & 25.02 & 23.79 (oven-dry) & $22.06 \%$ \\
Non-G-layer (oak tree 1) & 19.49 & 84.92 (oven-dry) & $204.59 \%$ \\
G-layer (oak tree 1) & 27.88 & 32.24 (oven-dry) & $29.69 \%$ \\
Non-G-layer (oak tree 2) & 24.86 & 68.73 (oven-dry) & $80.39 \%$ \\
G-layer (oak tree 2) & 38.10 & &
\end{tabular}

to the cell-wall area. In the chestnut and oak studies the difference was even higher in the dry state but with a higher dispersion when there was a high proportion of G-layer fibres (Fig. 6.5) (dry MOEs were not measured in the maple study). The increase of dispersion was explained by Clair et al. (2003c) as a possible consequence of some delamination between $\mathrm{S}_{2}$ and G-layers during drying but this hypothesis was later refuted by a study showing that delamination is a sample preparation artefact and does not occur in the core of a sample even after drying (Clair et al. 2005b). These studies proposed a simple mixture model to determine the MOE of separated components. Results are summarized in Table 6.1.

There is a greater increase in rigidity from the saturated to the air-dry states for tension wood than for normal wood (Fig. 6.6). This increase of rigidity can be 


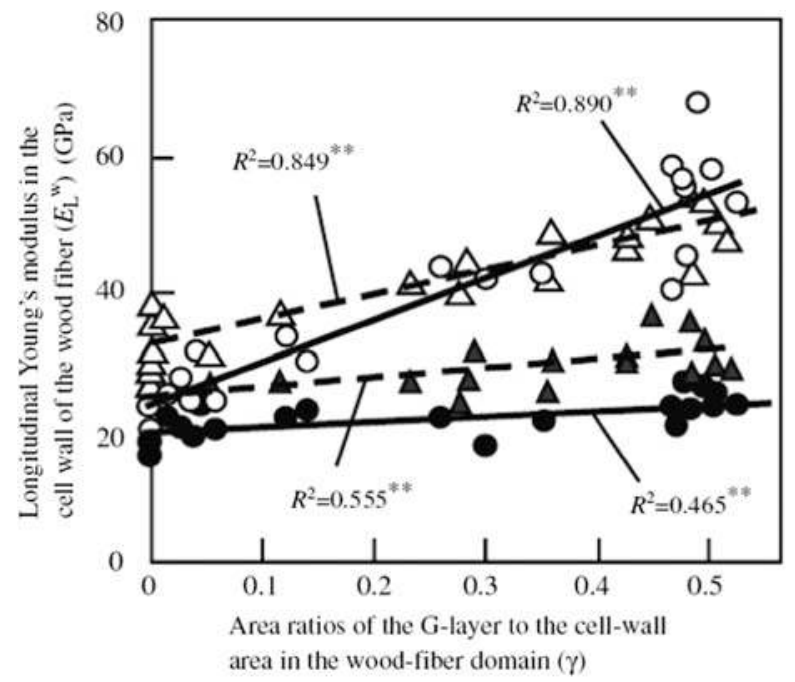

Fig. 6.6 Longitudinal Young's modulus in the cell wall of wood fibres versus the area ratio of the G-layer to the cell wall in the wood fibre domain. Circles and triangles represent two different oak trees. Filled symbols: wet condition, open symbols: dry condition (from Yamamoto et al. 2009)

attributed to the G-layer which increased by between 80 and $200 \%$. This stiffness increase is attributed by the authors to the xerogelation of the matrix, which loses its mesoporosity as shown by Clair et al. (2008) and allows stiff contact between microfibrils.

Experiments on mechanical properties at the level of the cell wall layers need the use of specialized microscopic techniques such as nano-indentation or atomic force microscopy. Few studies on reaction wood have been made using these techniques. Using nano-indentation, Gindl et al. (2004) reported a lower MOE in compression wood compared with any other wood type in Norway spruce (Picea abies (L.) H. Karst.) and commented on the good relationship of MOE with MFA. Konnerth and Gindl (2006) confirmed these observations in another study in which they observed mild compression wood. Regarding tension wood, only one reference shows mapping of elastic properties by atomic force modulation microscopy (Clair et al. 2003a). The G-layer, observed in the dry condition, appeared stiffer than other layers (Fig. 6.7). Authors describing both nano-indentation and atomic force modulation microscopy studies noted the limitations of the methods and pointed out that elastic moduli of wood cell walls determined by these techniques have to be interpreted with caution.

\subsubsection{Transverse Elastic Properties}

Timell (1986) reported no studies of transverse elastic properties of reaction wood and only one measurement has been reported by Placet et al. (2007) for spruce 

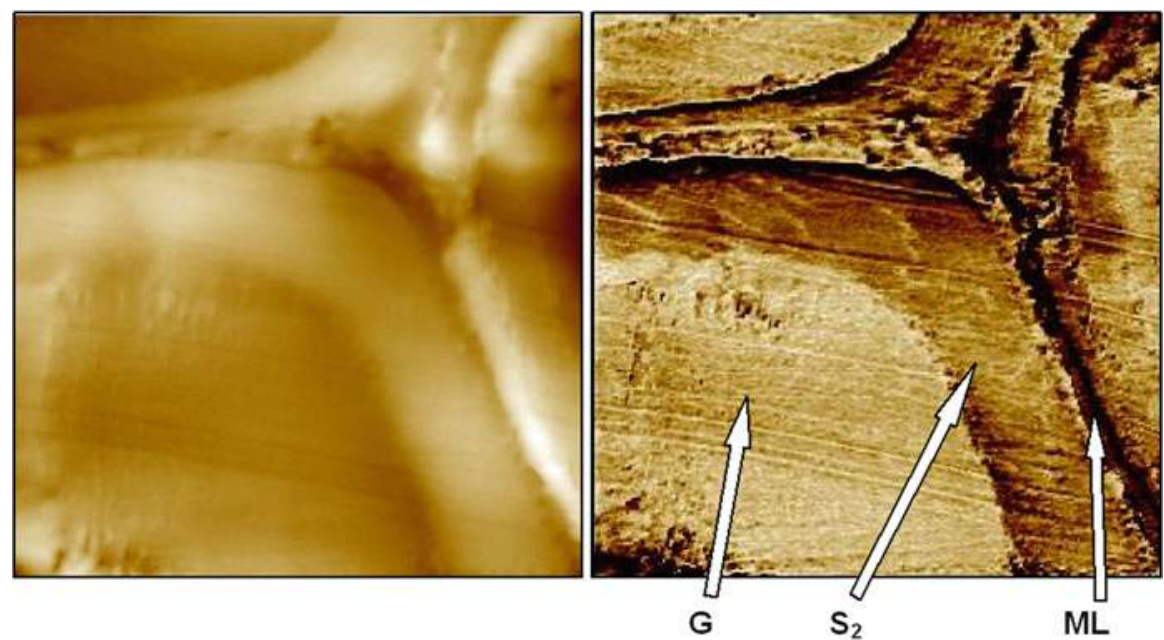

Fig. 6.7 Images obtained with atomic force modulation microscopy. Left: topographic image of oak tension wood cell wall. Right: corresponding image of elasticity. A lighter colour indicates higher rigidity than darker ones. G: G-layer, $\mathrm{S}_{2}$ layer, ML: middle lamella (from Clair et al. 2003a)

compression wood in the wet condition where the storage modulus was found to be almost fivefold higher compared to normal wood in the tangential direction (CW: $447 \mathrm{MPa}$, NW: $84 \mathrm{MPa})$.

Passard and Perré (2005) used the cantilever bending test on wet oak wood and found that regardless of the direction, wet tension wood was less stiff than normal wood. In the radial direction they found a mean of $687 \mathrm{MPa}$ for normal wood and a mean of $607 \mathrm{MPa}$ for tension wood. Similarly, in the tangential direction, the modulus was found to be around $398 \mathrm{MPa}$ in normal wood and $354 \mathrm{MPa}$ in tension wood. Later, using a dynamic test at $1 \mathrm{~Hz}$, Placet et al. (2007) found a greater difference between the wood types in similar conditions (tangential OW: $242 \mathrm{MPa}$, tangential TW: $146 \mathrm{MPa}$, radial OW: $680 \mathrm{MPa}$, radial TW: $495 \mathrm{MPa}$ ). Similar results were obtained on dry wood when Dinh et al. (2008) did a four point static bending test on millimetric samples of dry poplar and reported that differences in Young's modulus between normal and opposite wood and tension wood were low. Otherwise, MOE is lower in tension wood in both radial and tangential directions, from $E=400 \mathrm{MPa}$ (TW) to $500 \mathrm{MPa}(\mathrm{NW})$ in the tangential direction and from $E=1,200 \mathrm{MPa}(\mathrm{TW})$ to $1,500 \mathrm{MPa}(\mathrm{NW})$ in the radial direction. They explained this by the lack of cohesion of the G-layer with the rest of the wall, but following results from the study on the detachment of the G-layer (Clair et al. 2005b), an alternative explanation could be the very low transverse modulus in the G-layer resulting from its low MFA and the absence of lignin. In these cases, the part of the tension wood fibre wall contributing to the mechanical properties would be thinner than in normal wood fibre walls $\left(S_{1}+S_{2}\right.$ layers only rather than $S_{1}+S_{2}+S_{3}$ layers). 


\subsubsection{Shear Modulus}

Very little work has been carried out into this question. Timell (1986) cited only two studies where shear modulus was found to be larger for compression wood than normal wood by a factor 2 . No data were found concerning tension wood.

\subsubsection{Strength Properties}

\subsubsection{Strength in Compression Wood}

In the studies reported by Timell (1986), compression wood was generally stronger in compressive strength than normal wood, i.e. it can sustain a higher maximum load before failure. However, when taking into account the higher density of compression wood, compression wood is surprisingly similar to normal wood, being sometimes slightly stronger, sometimes slightly weaker. Gindl et al. (2001) showed that the compression and bending strength of compression wood increase proportionally with increasing density as is the case in normal wood. Gindl (2002) showed that compressive strength of compression wood was not negatively affected by the high MFA and suggested that the high lignin content in compression wood increases the resistance of the cell walls to compression failure.

During drying, strength properties generally increase, but compression wood generally improves less than does normal wood. Another strength property is the stress at proportional limit denoting the maximum stress at which load and strain are still proportional. For this property, compression wood appears weaker than normal wood.

Compression wood, like normal wood also has a higher tensile than compressive strength although results have been contradictory with regard to comparisons between the two wood types with compression wood being generally found to be weaker than normal wood although sometimes it has been reported to be stronger (Timell 1986).

Recently, Reiterer et al. (1999) testing $200 \mu \mathrm{m}$ thin sections, showed that strain at maximum stress before rupture was higher in compression wood and was governed by MFA. The data for stress at the proportional limit in tension shows compression wood to be much weaker than normal wood.

Gindl and Teischinger (2003) found shear strength of compression wood to be significantly higher than expected on the basis of its density compared to normal wood. They found that the specific shear strength was $23.2 \mathrm{MPa} \mathrm{cm} \mathrm{g}^{-1}$ for compression wood compared to $17.7 \mathrm{MPa} \mathrm{cm} \mathrm{g}^{-1}$ for normal wood. 

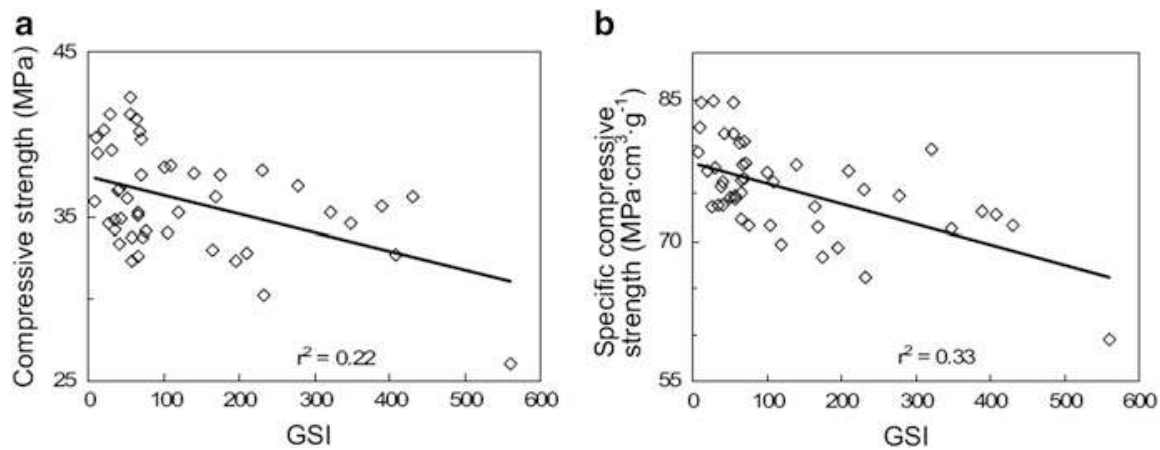

Fig. 6.8 Relationships of (a) compressive strength (MPa) and (b) specific compressive strength $\left(\mathrm{MPa} \mathrm{cm} \mathrm{g}^{-1}\right.$ ) with growth stress indicator (GSI, $\mu \mathrm{m}$ ) (from Fang et al. 2008a)

\subsubsection{Strength in Tension Wood}

Clarke (1937) reported that beech (Fagus spp.) tension wood was weaker under compression than normal wood and observed that tension wood failed by buckling, whereas normal wood had a shear type failure. He also reported that, under tension, a wide range of variation was found both in normal wood and tension wood, with tension wood on average stronger than normal wood. Similarly, Dadswell and Wardrop (1955) reported little difference in tensile strength between tension wood and normal wood. Ruelle et al. (2007a) reported that among ten species, only one showed a significant difference between tension and opposite wood for flexure and compressive strength. For the other species, no predominant tendency was found; sometimes tension wood was more resistant, at other time, opposite wood was more resistant. Fang et al. (2008a) reported a significant decrease of compressive strength from normal wood to tension wood in poplar (Fig. 6.8a). These results are understandable when plotting the specific compressive strength (Fig. 6.8b) since the decrease of compressive strength is accompanied with an increase of density from normal wood to tension wood in the samples.

The lower compressive strength in tension wood could be explained by the lower lignin content especially in the G-layer, allowing easy buckling of the cell wall giving rise to the formation of slip planes and minute compression failures as observed by Wardrop and Dadswell $(1948,1955)$.

\subsection{Consequences of Internal Stresses on Wood Properties}

\subsubsection{Boiling and Hygrothermal Recovery}

The internal stresses accumulated during the life of the tree are partially released through strain during sample or board preparation. However, some strains still 
remain in the wood. These locked in strains will be released with time or with hygrothermal treatment, so-called hygrothermal recovery (HTR) (Kubler 1987). Little research has been carried out on the HTR of reaction wood. No data have been found by the authors on compression wood and just two publications refer to tension wood both on chestnut wood. Gril et al. (1993) found a clear difference of HTR in the tangential direction between tension wood and normal wood and also with opposite wood $(\mathrm{NW}=0.55 \%, \mathrm{OW}=0.3 \%, \mathrm{TW}=0.85 \%)$. The ratios between wood types were as follows, $\mathrm{TW} / \mathrm{NW}=1.5$ and $\mathrm{OW} / \mathrm{NW}=0.5$. In another study dealing with the contribution of internal stress to drying shrinkage (Clair 2012) it was shown that hygrothermal swelling stain along the tangential direction was clearly higher in tension than normal wood $(\mathrm{NW}=0.15 \pm 0.15$; $\mathrm{TW}=0.58 \pm 0.26$ ). Similarly, along the longitudinal direction, normal wood slightly swells $(\mathrm{NW}=0.58 \pm 0.26)$, whereas tension wood significantly shrinks $(\mathrm{TW}=-0.14 \pm 0.05)$. This clear difference between wood types is directly connected to the stress level that can be expected in the tree.

In a study on the effect of boiling on Zelkova serrata tension wood, Abe and Yamamoto (2007) showed that longitudinal shrinkage on drying is less after boiling compared to unboiled samples. This could result from the initial release of strain by thermal treatment. The effect was higher when the amount of G-layer was greater in the sample. It can be deduced from this study that boiling affects the longitudinal Young's modulus, which is lower than in unboiled green wood.

\subsubsection{Behaviour During Solvent Exchange}

Kubler (1987) observed that solvent seems to trigger HTR without heat. Recently Chang et al. (2009b, 2012) made a similar observation of strain following various solvent treatments. The observed strain along the longitudinal direction allows a clear separation of wood types between normal wood and tension wood both in chestnut and poplar, which produce typical G-layers, and Simarouba amara having tension wood without a G-layer (Ruelle et al. 2007b). Whereas normal wood exhibits swelling linked to the difference of molecular size between water and ethanol, tension wood exhibits $0.05 \%$ shrinkage. In the tangential direction no differences were found between wood types. When cycling between water and ethanol is performed, poplar tension wood samples always continue to shrink in the longitudinal direction both in sorption and desorption up to an asymptotic limit (Clair, unpublished data). 


\subsection{Drying Behaviour}

Wood is subject to dimensional changes during drying. Normal wood shrinks about 4-6\% in the radial direction and around $8-10 \%$ in the tangential direction, but much less in the longitudinal direction (around $0.1 \%$ ). Shrinkage along the radial and tangential directions is due to a combination of effects at the cell wall level and effect of structure linked to the organization and the shape of the cells. In the longitudinal direction, differences in shrinkage are explained mainly by differences in MFA in the $S_{2}$ layer (which is the thickest layer of the cell wall). In fact, the crystalline nature of cellulose make it quasi-non-deformable, thus, water movement only affects dimensions perpendicular to microfibrils (shrinkage is quasi-null along cellulose microfibrils and maximum transverse to them). The larger the MFA, the more the axial shrinkage and the less the transverse shrinkage of the wall. This has been largely verified experimentally and modelled (e.g. Barber and Meylan 1964; Barber 1968; Cave 1969, 1972a, b; Barrett et al. 1972; Boyd 1977; Gril et al. 1999; Yamamoto 1999)

\subsubsection{Drying Shrinkage of Compression Wood}

Because compression wood has a very high longitudinal shrinkage compared to normal wood, its presence in wood products decreases its value considerably. Heterogeneity in wood products produces warps and splits. Thus, numerous studies have been made on the drying shrinkage of compression wood. Timell (1986) reviewed the earlier ones and from the huge number of experiments presented the following conclusions can be drawn (shrinkage being calculated as the difference in length between green and oven-dry condition compared with green length): longitudinal shrinkage has been found generally to lie between 1 and $3 \%$ with maximum values in some cases up to $6 \%$. Thus longitudinal shrinkage is generally 8-15 times higher than in normal wood and up to 40 times higher in some cases. In the radial direction, shrinkage is around 1.5-3\%, between a third and a half of what was found in associated normal wood. Tangential shrinkage is around 3-4.5\%, e.g. 40-60\% less than in normal wood. Although authors have considered the contribution of the high lignin content, the lower crystallinity of cellulose and some structural aspect such as the lack of $\mathrm{S}_{3}$ and the circularity of the cells in compression wood, the key role of the larger MFA is regarded as the main factor influencing the high longitudinal shrinkage of compression wood. 


\subsubsection{Paradoxical Longitudinal Shrinkages of Tension Wood}

\subsubsection{Historic}

In 1949, Onaka (1949) remarked on the lack of studies on the shrinkage of tension wood and reported an experiment comparing flexion during the drying of $30 \mathrm{~cm}$ long portions of branches of various hardwood and softwood species (Fig. 6.9). He noted that the bending is towards the lower side in conifers (compression wood side) and on the upper surface in deciduous trees (tension wood side). And he adds: "however, in such species as Meliosma tenuis Maxim. Meliosma myriantha Sieb. and Zucc. and Tilia japonica Smik. In which the gelatinous layer does not appear, no such bending is observed. Thus, such changes could be attributed to the presence of the gelatinous layer. It must shrink markedly in the longitudinal direction in drying".

From 1937 up to the 1950s, several studies of high longitudinal shrinkage in tension wood with a G-layer have been described (Clarke 1937; Chow 1946; Onaka 1949; Akins and Pillow 1950; Pillow 1956; Terrell 1953; Wardrop and Dadswell 1955). These studies highlight the relationship between this particular layer and the high shrinkage but there is no microscopic interpretation of the phenomenon. The link with density has been studied by several authors and confirms the absence of any clear relationship (Terrell 1953). The G-layer is widely believed to be the cause of the high shrinkage of tension wood, which is responsible for numerous technological problems such as splitting and distortion.

The G-layer was discovered by Hartig in the late nineteenth century and has been variously called by different authors "cellulosic layer", "mucilaginous layer", "cartilaginous layer", or "gelatinous layer" due to its high cellulose content, its detachment from other layers and its gelatinous appearance that gives it its irregular and swelled appearance (Sanio 1860a, b, 1863; Metzger 1908; Potter 1924). The name gelatinous layer (or G-layer) has now been generally adopted. Its structure has been described as highly cellulosic, highly crystalline and with a very low angle of microfibrils relative to the direction of the fibre. Despite extensive study, Wardrop and Dadswell (1955) were unable to explain the longitudinal shrinkage from the microstructure point of view since the classical conception of wood behaviour would predict a very low longitudinal shrinkage because of the low MFA.

In 1966, Norberg and Meier (1966) were the first to make shrinkage measurements at a microscopic level. They isolated portions of G-layers using an ultrasonic method and measured their length under the light microscope first in water and then after drying (Fig. 6.10). They concluded that the G-layer shows no longitudinal shrinkage (or too weak to be the cause of macroscopic longitudinal shrinkage) and they looked for an explanation for the shrinkage in other parts of the structure. As the G-layer often appears detached from the other wall layers they assumed it did not contribute to the shrinkage, but that it did not limit it either. They concluded that as the $S_{2}$ layer is generally thinner in the presence of a G-layer, the proportion of $S_{1}$ layer becomes significant in the wall and the MFA being greater than $40^{\circ}$ in $S_{1}$, 
Fig. 6.9 Bending of branches during drying for several species. Full line: green state, dotted line: dry state (adapted from Onaka 1949)

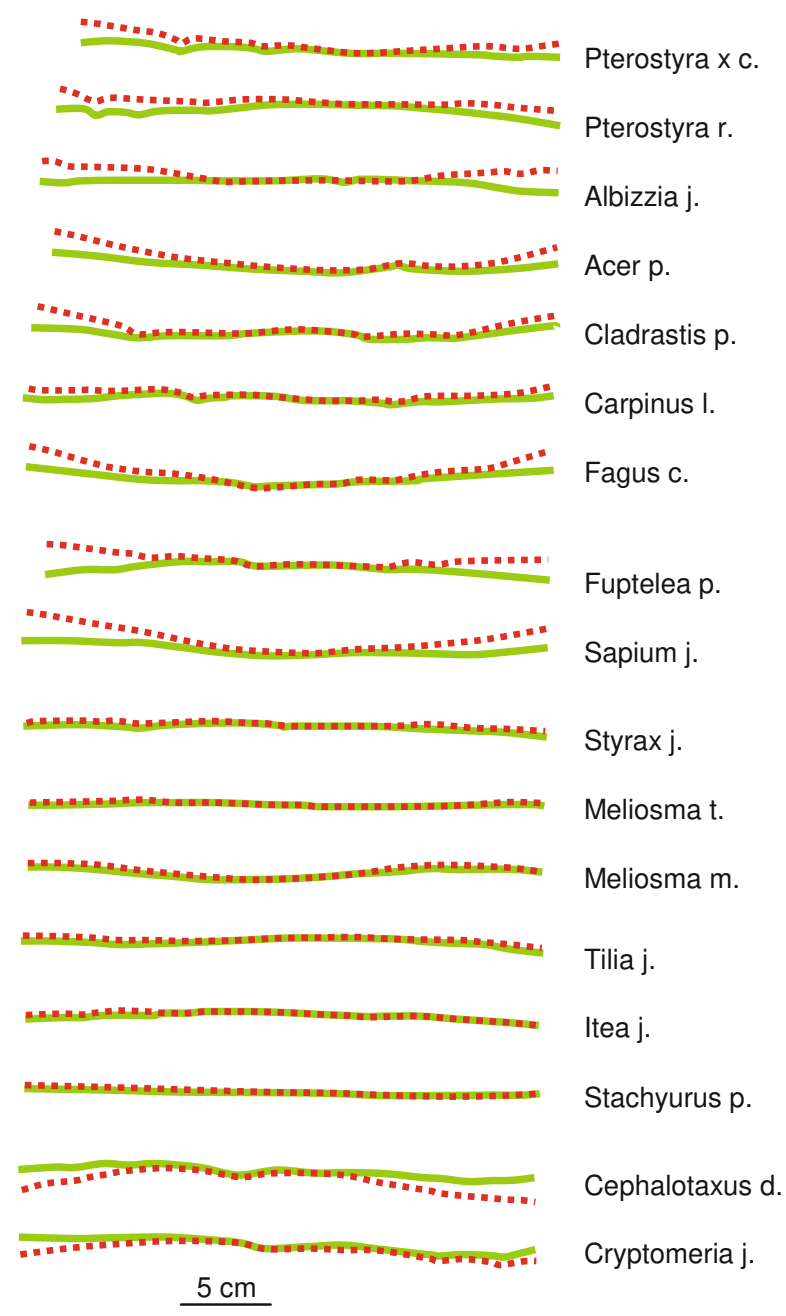

the authors attribute to the $S_{1}$ the high shrinkage observed in tension wood containing a G-layer. Later, Boyd (1977) also supported this hypothesis. These two articles are widely cited and the issue seemed settled.

\subsubsection{The Key Role of G-Layer in Macro-Shrinkage}

Amount of G-Layer Governs the Magnitude of Longitudinal Shrinkage

At the end of the 1990s, studies continued to report the higher longitudinal shrinkage of tension wood and its relationship with the amount of G-layer 


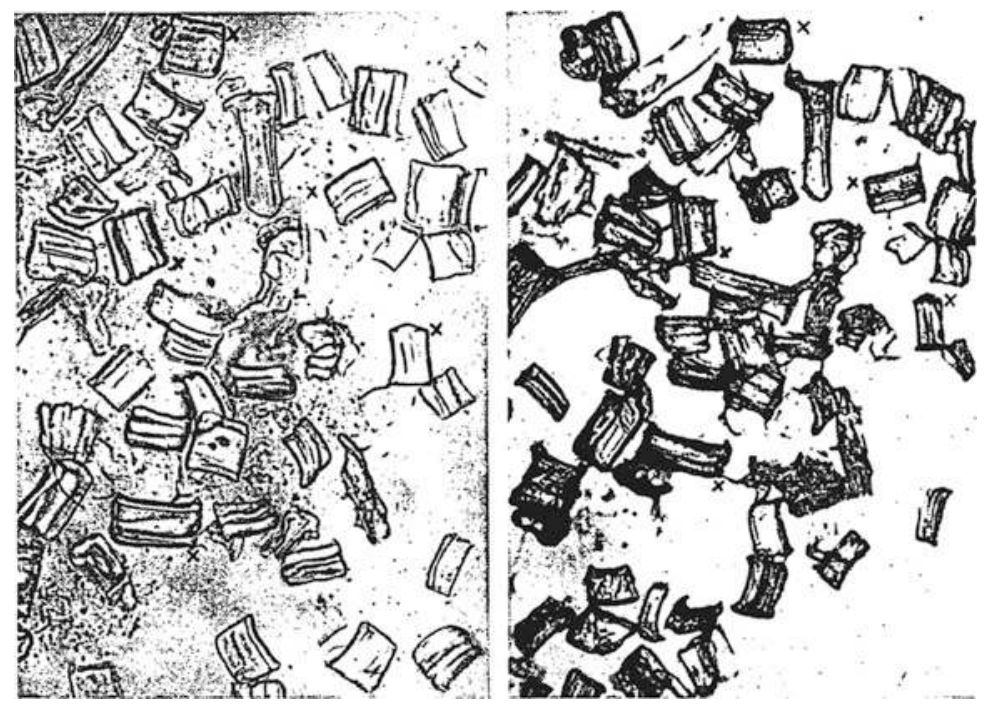

Fig. 6.10 Isolated portion of G-layer in wet (left) and dry (right) conditions (from Norberg and Meier 1966)

(Grzeskowiak et al. 1996; Jourez et al. 2001a; Washusen et al. 2001; Washusen and Evans 2001; Washusen and Ilic 2001). Clair et al. (2003c) investigated longitudinal shrinkage, the MOE and the proportion of fibres with a G-layer using the same chestnut samples as used to measure MOE (see Sect. 6.3.1) (Fig. 6.11). Using a simple mixture model it was possible to determine the longitudinal shrinkage of both fibres with a G-layer and fibres without a G-layer. They found $0.34 \%$ longitudinal shrinkage for non-G-layer fibres and $0.71 \%$ for G-layer fibres. Latter, Yamamoto et al. (2005) did similar work but with a more detailed description of the anatomy in which the G-layer itself was compared to the other layers. They found $1.30 \%$ longitudinal shrinkage in the G-layer compared to $0.28 \%$ in other layers.

Observation of Longitudinal Shrinkage at the Cell Wall Level

Following an original idea from Professors Yamamoto and Okuyama (Nagoya University), Clair and Thibaut (2001) measured the longitudinal shrinkage of the G-layer using stereo imaging with scanning electron microscopy and atomic force microscopy (Fig. 6.12). They showed that the G-layer shrinks more than other layer in passing from water saturated conditions to the air-dry condition. This shrinkage, partially reversible, was found to be about $4 \%$ but a later study proved that this value was overestimated since part of the strain had already occurred before drying due to the release of maturation stress in the G-layer during sample sectioning (Clair et al. 2004, 2005b). The longitudinal shrinkage of the G-layer itself being proved, in order to contradict the Norberg and Meier hypothesis it was necessary to 

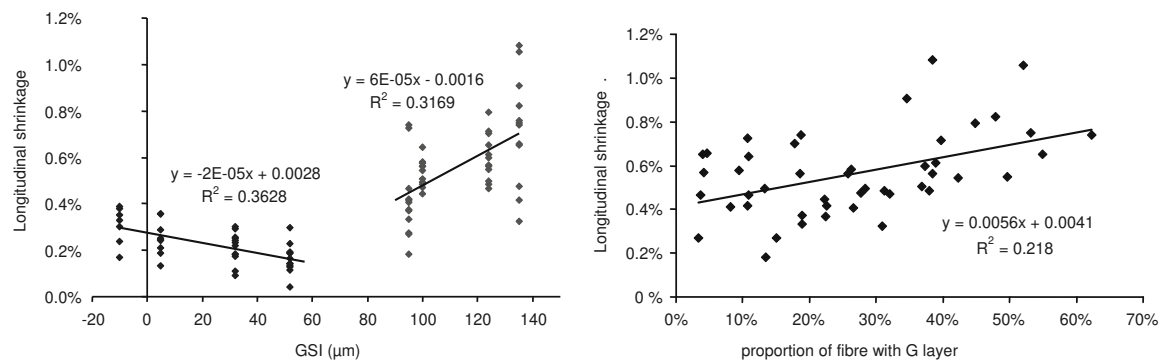

Fig. 6.11 Disjointed relationship between longitudinal shrinkage and growth stress indicator (GSI) and relationship with the amount of fibres with a G-layer (Clair et al. 2003c)

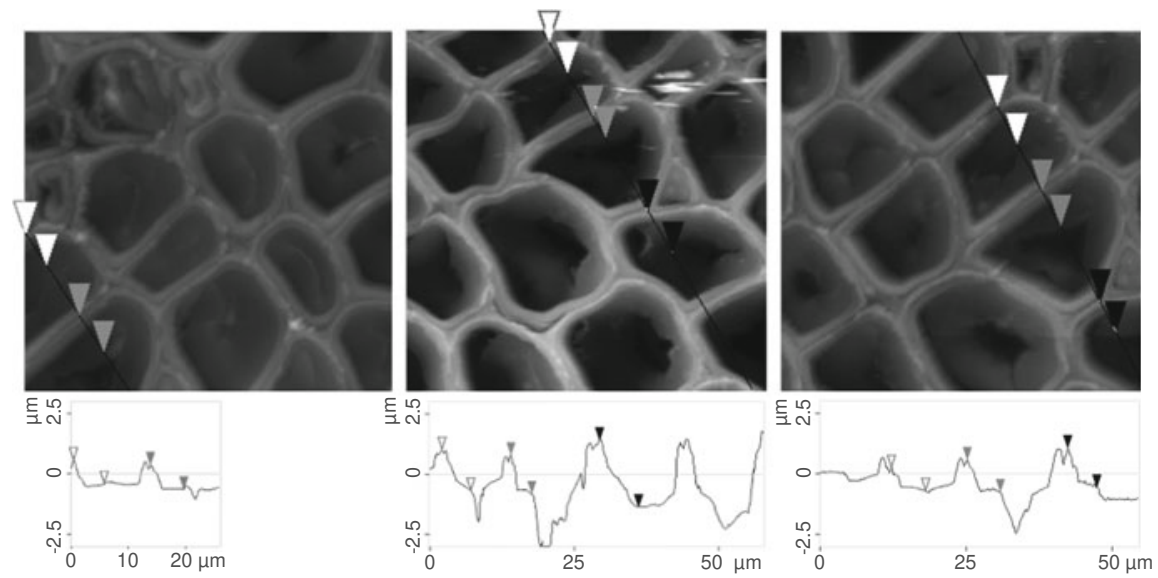

Fig. 6.12 Measurement on topographic profiles on AFM images of the same poplar tension wood cells in never-dried condition under water (left), air-dry (centre), and wet again conditions (right) (from Clair and Thibaut 2001)

verify the adherence of the G-layer to the $S_{2}$ layer. In a dedicated study it was proved that detachment of G-layer is an artefact arising during sample preparation and that it is not present in the core of wood sample, even after drying (Clair et al. 2005a). Therefore, the G-layer does appear to have a role in the high longitudinal shrinkage in tension wood.

\subsubsection{Origin of G-Layer Shrinkage: Its Porous Structure}

Earlier investigations seemed to prove that the G-layer is the driving force for longitudinal shrinkage, but the mechanism of the shrinkage remains enigmatic. In normal softwood, Abe and Yamamoto (2005) showed that cellulose microfibrils 
shrink linearly with decreasing moisture content. In a later study concerning the contribution of cellulose microfibrils to growth stress generation, Clair et al. (2006a) investigated the strain of cellulose during drying of poplar tension wood. They observed that cellulose shrinks between 0.008 and $0.04 \%$ when macroscopic shrinkage is about $0.8-1 \%$. Therefore, in tension wood, cellulose should buckle during the shrinkage process and thus cannot be the driving force behind shrinkage.

Thus, interest must be turned to the texture of the matrix. Thanks to the technique of nitrogen adsorption-desorption isotherms, supercritically dried chestnut tension wood has been characterized as having a gel-like mesoporous structure characterized by a pore surface more than 30 times higher than that in normal wood and attributed to the G-layer (Clair et al. 2008). When isotherms were done using oven-dry tension wood, all mesoporosity of the gel disappeared indicating that the gel collapsed during drying. This gel collapse is strong enough to be the driving force of cellulose microfibril buckling. Then the high longitudinal shrinkage of the G-layer and its transmission to the whole fibre, thanks to its adhesion to the other layers of the secondary wall, produces a macroscopic longitudinal shrinkage that sometimes exceeds $1 \%$ in tension wood. In recent years several research teams (Lafarguette et al. 2004; Nishikubo et al. 2007; Bowling and Vaughn 2008; Ikushima et al. 2008; Mellerowicz et al. 2008; Baba et al. 2009; Kaku et al. 2009; Hayashi and Kaida 2010) have worked on the description of the nature of the non-cellulosic part of the G-layer among which pectins and xyloglucans appear to be good candidates for the origin of the gel structure of the G-layer. These ideas were previously hypothesized by Sachsse (1965) but latter forgotten after being rejected by Norberg and Meier (1966).

\subsubsection{What About Longitudinal Shrinkage of Non-G-Layer Tension Wood?}

Many species form tension wood without a G-layer (Onaka 1949; Fisher and Stevenson 1981). However, all of them have lower MFAs in tension wood than in normal wood (Clair et al. 2006b). In experiments on branches (see Fig. 6.9 at the beginning of this section), Onaka (1949) noted that some species do not bend during shrinkage when no tension wood was formed (i.e. no G-layer observed). Even so, Ruelle et al. (2007a) comparing properties of ten tropical species reported that "longitudinal shrinkage was often the most significantly different property between tension and opposite wood, four to seven times higher in tension wood for seven species, but less than two times higher for Simarouba amara Aubl., Eschweilera decolorens Sandw. and Qualea rosea". Two of these genera (Simarouba and Eschweilera) are known to produce tension wood without a G-layer (Clair et al. 2006b; Ruelle et al. 2007b). More recently, Ruelle et al. (2011) confirmed that Simarouba amara has a longitudinal shrinkage around two times higher than its normal wood. This longitudinal shrinkage is much less than in tension wood with a 
G-layer but is still paradoxical considering the lower MFA than in normal wood. Recently, Chang et al. (2009a) tried to find some mesoporosity in tension wood without a G-layer. However, their results showed that tension wood without a G-layer does not have mesoporosity and that even some species with a thin, un-swollen G-layer do not show mesoporosity. Recently, a study produce evidence that the release of maturation stress during drying is an answer to this paradox.

Following ethanol exchange in chestnut and Simarouba never-dried tension wood, Chang et al. (2009b) shown that tension wood of both species (with and without a G-layer) shrinks about $0.05 \%$ in the longitudinal direction. The observed phenomena are explained as a kind of hygrothermal recovery occurring during the departure of water molecules due to exchange with ethanol. A similar process could occur during drying. Previously, Abe and Yamamoto (2007) show on Zelkova serrata tension wood that longitudinal drying shrinkage is less after boiling compared to unboiled samples. Similarly, it has been recently showed that the longitudinal shrinkage of chestnut tension wood is lower when it has been previously heated. Measurement using replicates, dried with or without heat treatment (HT), gave the following results: HT strain $=-0.14 \% \pm 0.05 \%$; drying strain after $\mathrm{HT}=-0.64 \% \pm 0.05 \%$; drying strain without $\mathrm{HT}=-0.78 \% \pm 0.08 \%$. This means that the strain released during heat treatment was part of the total strain generally measured in tension wood. Thus, longitudinal shrinkage could be a combination of three effects at the cell wall level: (1) the effect of the loss of spaces occupied by water (which depends highly on MFA and so does not affect tension wood very much), (2) the effect of stress recovery which is visible mainly in high tension stressed wood (tension wood), and (3) the effect of gel collapse, far higher than the previous effects, but occurring only in G-layer tension wood (Fig. 6.13).

\subsubsection{Transverse Shrinkage of Tension Wood}

Fewer studies have been done on the transverse shrinkage of tension wood and the results are contradictory. Washusen et al. $(2001,2001)$ on eucalyptus and Clair et al. (2003c) on chestnut reported a higher tangential shrinkage in tension wood, while Arganbright et al. (1970) observed a lower shrinkage in silver maple (Acer saccharinum) tension wood both in tangential and radial direction. In beech tension wood, Clarke (1937) reported that shrinkage was higher than in normal wood in the tangential direction but not in the radial direction. Clair et al. (2003b) measured a higher shrinkage both in the radial and tangential directions in mani (Symphonia globulifera), but found that the difference was clearer in the tangential direction. In the case of the ten tropical species studied by Ruelle et al. (2007a), tangential shrinkage was always higher in tension wood, except for Eperua falcata in which tangential shrinkage was very low, and the difference was significant for only four trees. Along the radial direction, shrinkage was found to be sometimes higher, sometimes lower in tension wood, with only three significant differences (one lower 


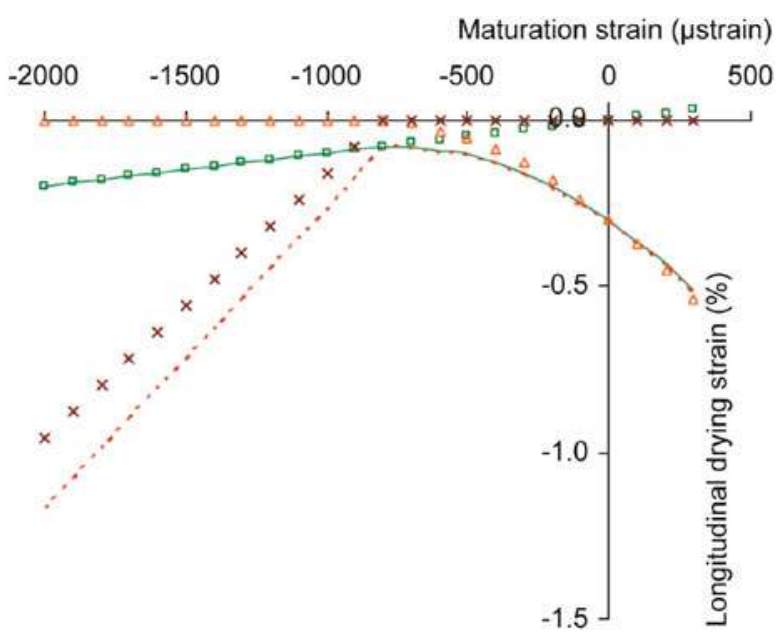

Fig. 6.13 Schematic model of the three cumulative contributions to longitudinal shrinkage as a function of the maturation strain. Green squares: strain caused by stress release; orange triangles: strain caused by water departure; crosses: strain caused by G-layer collapse. Plain line (green): resulting shrinkage on wood from species not producing a G-layer; dotted line (red): resulting shrinkage on wood from species producing a G-layer. Release strain is proportional to growth strain, water departure strain depends on MFA and gel collapse depends on the amount of gel in the wood sample (from Clair 2012)

and two higher for tension wood). Recently, Fang et al. (2007) carried out shrinkage measurement on $20 \mu \mathrm{m}$ thick sections. They recorded a significant negative correlation with the measured growth stress (directly linked to the amount of G-layer (Fang et al. 2008b) in the tangential direction whereas no relationship was found in the radial direction).

In a recent study about the contribution of maturation stress on shrinkage, it was found that the release of transverse compressive stress during drying contribute to reduce the tangential stress in tension wood of chestnut (Clair 2012). At the cell wall level, several authors point to the very large transverse shrinkage of the G-layer. Norberg and Meier (1966) found it to be around 15-25\% on isolated G-layers. Recently, Fang et al. (2007) measured the shrinkage of the G-layer keeping it in its cellular context and avoiding preparation artefacts (Clair et al. 2005c). They found that G-layer shrinkage is around $12-27 \%$ and that this shrinkage remains constant for several levels of growth stress (and therefore different G-layer thicknesses). Their observations showed that in G-fibres, lumen size increased during drying and this increase was positively related to G-layer thickness whereas in normal wood fibres, lumen size decreased during drying. These findings suggest that the G-layer shrank outwards (i.e. its internal perimeter increased) because of the absence of $S_{3}$ layer (Fig. 6.14), so that its shrinkage weakly affected the total cell shrinkage. Thus, in tension wood with a G-layer, 


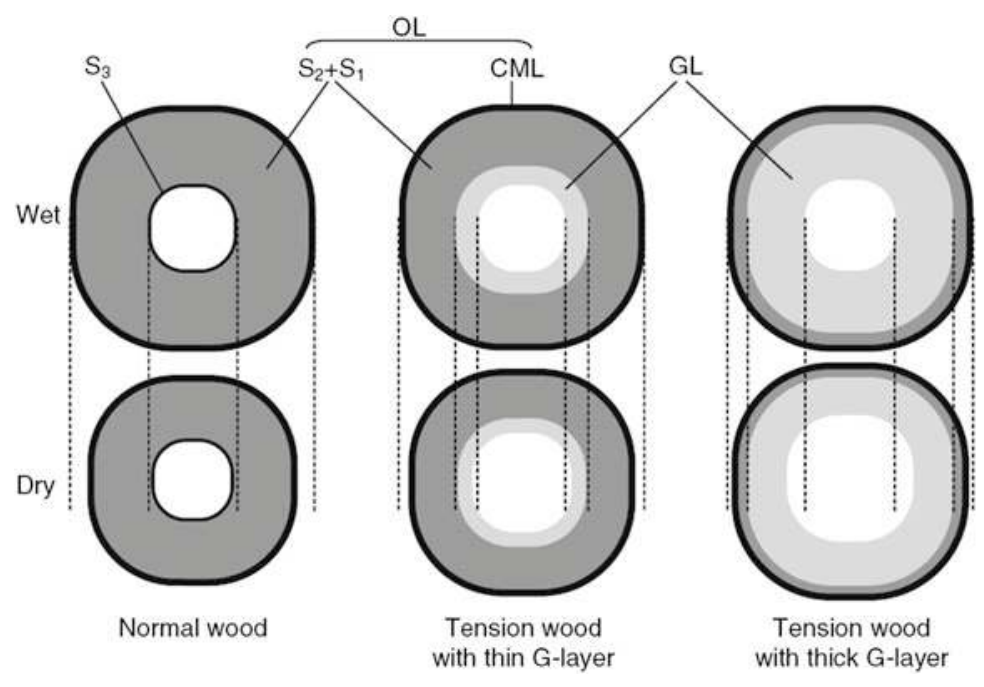

Fig. 6.14 Three shrinkage scenarios starting from the same cell and lumen size, depending on the proportion of the cell wall layers. $O L$ other layers, $C M L$ compound middle lamella, $G L$ gelatinous layer (Fang et al. 2007)

the macroscopic shrinkage would be mainly controlled by the shrinkage of other layers (ML, $\mathrm{S}_{1}, \mathrm{~S}_{2}$ : see Chaps. 2 and 3 for discussion of wood cell structure) which shrank inwards (i.e. its external perimeter decreases).

\subsection{Conclusion}

Both compression and tension wood are produced by the cambium at a given place within a woody axis in order to create a dissymmetry in forces on opposite sides of this axis. It is very likely that wood genesis by the cambium in these cases is strongly different from wood genesis for all "normal" woods, juvenile or mature, side or opposite, with specific genes involved and quite different chemical composition of basic cell wall constituents. Reaction wood does not seem to be an extreme case of normal wood.

The basis of different forces on opposite sides of the axis is a very different value of maturation strain in fibre cell wall during cell differentiation: opposite to normal for compression wood, three to six times higher for tension wood. This is achieved by both a radical change in chemistry and the peculiar orientation of MFA (always very high values for compression wood and always very low values for tension wood).

Forces result from the combination of maturation strain, density, and width of the newly formed ring. Thus reaction wood formation can be often associated with 
changes in density and ring width, peculiarly in the case of compression wood, in order to compensate the huge reduction in specific MOE associated with high MFA values.

Thus physical and mechanical changes in properties from normal to reaction wood are more important for compression wood: higher density associated with higher rupture strength in compression and hardness, lower MOE, lower radial, tangential and volumetric shrinkage but much higher longitudinal shrinkage (ten times more at least).

For tension wood, the only common change is a higher longitudinal shrinkage (up to $1 \%$ in many cases). Sometimes density and transverse shrinkage is also higher but may also be lower. This is the reason why tension wood is often not considered as a big problem, whereas the high level of residual stresses and stored elastic energy in the log are the biggest problem for hardwoods leading to, for example, log splitting and lumber twisting.

It should be noted that the very essence of the reaction wood mechanism, dissymmetry between two faces of a $\log$, leads to strong heterogeneity within lumber pieces containing both normal and reaction wood. Associated with the differences in longitudinal shrinkage between the two types of wood this leads to the main problem with reaction wood in use. These issues will be dealt with in more detail in Chaps. 8 and 9.

\section{References}

Abe K, Yamamoto H (2005) Mechanical interaction between cellulose microfibril and matrix substance in wood cell wall determined by X-ray diffraction. J Wood Sci 51:334-338

Abe K, Yamamoto H (2007) The influences of boiling and drying treatments on the behaviors of tension wood with gelatinous layers in Zelkova serrata. Int J Wood Sci 53:5-10

Akins V, Pillow MY (1950) Occurrence of gelatinous fibres and their effect upon properties of hardwood species. Proc US For Prod Res Soc 4:254-264

Alméras T, Thibaut A, Gril J (2005) Effect of circumferential heterogeneity of wood maturation strain, modulus of elasticity and radial growth on the regulation of stem orientation in trees. Trees Struct Funct 19:457-467

Arganbright DG, Bensend DW, Manwiller FG (1970) Influence of gelatinous fibers on the shrinkage of silver maple. Wood Sci 3:83-89

Astley RJ, Stol KA, Harrington JJ (1998) Modelling the elastic properties of softwood. II. The cellular microstructure. Holz Roh Werkst 56:43-50

Baba K, Park Y, Kaku T, Kaida R, Takeuchi M, Yoshida M, Hosoo Y, Ojio Y, Okuyama T, Taniguchi T, Ohmiya Y, Kondo T, Shani Z, Shoseyov O, Awano T, Serada S, Norioka N, Norioka S, Hayashi T (2009) Xyloglucan for generating tensile stress to bend tree stem. Mol Plant 2:893

Baillères H (1994) Précontraintes de croissance et propriétés mécano-physiques de clones d'Eucalyptus (Pointe Noire-Congo): hétérogénéités, corrélations et interprétations histologiques. Thesis. Université de Bordeaux 1 s.n. Bordeaux, 162 pp

Barber NF (1968) A theoretical model of shrinking wood. Holzforschung 22:97-103

Barber NF, Meylan BA (1964) The anisotropic shrinkage of wood. Holzforschung 18:146-156

Barrett JD, Schniewind AP, Taylor RL (1972) Theoretical shrinkage model for wood cell wall. Wood Sci 4:178-192 
Bowling AJ, Vaughn KC (2008) Immunocytochemical characterization of tension wood: gelatinous fibers contain more than just cellulose. Am J Bot 95:655-663

Boyd JD (1977) Relationship between fibre morphology and shrinkage of wood. Wood Sci Technol 11:3-22

Boyd JD (1980) Relationships between fibre morphology, growth strains and physical properties of wood. Aust For Res 10:337-360

Brémaud I, Ruelle J, Thibaut A, Thibaut B (2013) Changes in vibrational properties between compression and normal wood: roles of microfibril angle and of lignin. Holzforschung 67:75-85

Burgert I, Jungnikl K (2004) Adaptive growth of gymnosperm branches-ultrastructural and micromechanical examinations. J Plant Growth Regul 23:76-82

Burgert I, Keckes J, Frühmann K, Fratzl P, Tschegg SE (2002) A comparison of two techniques for wood fibre isolation-evaluation by tensile tests on single fibres with different microfibril angle. Plant Biol 4:9-12

Burgert I, Fuhmann K, Keckes J, Fratzl P, Stanzl-Tschegg SE (2003) Microtensile testing of wood fibers combined with video extensometry for efficient strain detection. Holzforschung 57:661-664

Burgert I, Frühmann K, Keckes J, Fratzl P, Stanzl-Tschegg S (2004) Structure-function relationships of four compression wood types: micromechanical properties at the tissue and fibre level. Trees 18:480-485

Burgert I, Frühmann K, Keckes J, Fratzl P, Stanzl-Tschegg S (2005a) Properties of chemically and mechanically isolated fibres of spruce (Picea abies [L.] Karst.). Part 2: twisting phenomena. Holzforschung 59:247-251

Burgert I, Gierlinger N, Zimmermann T (2005b) Properties of chemically and mechanically isolated fibres of spruce (Picea abies [L.] Karst.). Part 1: structural and chemical characterisation. Holzforschung 59:240-246

Cave ID (1969) The longitudinal Young's modulus of Pinus radiata. Wood Sci Technol 3:40-48

Cave ID (1972a) A theory of the shrinkage of wood. Wood Sci Technol 6:284-292

Cave ID (1972b) Swelling of a fibre reinforced composite in which the matrix is water reactive. Wood Sci Technol 6:157-161

Chafe SC (1990) Relationships among growth strain, density and strength properties in two species of Eucalyptus. Holzforschung 44:431-437

Chang SS, Clair B, Ruelle J, Beauchêne J, Di Renzo F, Quignard F, Zhao GJ, Yamamoto H, Gril J (2009a) Mesoporosity as a new parameter for understanding tension stress generation in trees. J Exp Bot 60:3023-3030

Chang SS, Clair B, Gril J, Yamamoto H, Quignard F (2009b) Deformation induced by ethanol substitution in normal and tension wood of chestnut (Castanea sativa Mill.) and simarouba (Simarouba amara Aubl.). Wood Sci Technol 43:703-712

Chang SS, Quignard F, Di Renzo F, Clair B (2012) Solvent polarity and internal stresses control the swelling behavior of green wood during dehydration in organic solution. Bioresources 7:2418-2430

Chow KY (1946) A comparative study of the structure and chemical composition of tension wood and normal wood in beech (Fagus sylvatica L.). Forestry 20:62-78

Clair B (2001) Etude des propriétés mécaniques et du retrait au séchage du bois à l'échelle de la paroi cellulaire: essai de compréhension du comportement macroscopique paradoxal du bois de tension à couche gélatineuse. Thesis, Wood science ENGREF, Montpellier, 152 pp

Clair B (2012) Evidence that release of internal stress contributes to drying strains of wood. Holzforschung 66:349-353

Clair B, Thibaut B (2001) Shrinkage of the gelatinous layer of poplar and beech tension wood. IAWA J 22:121-131

Clair B, Arinero R, Lévêque G, Ramonda M, Thibaut B (2003a) Imaging the mechanical properties of wood cell wall layers by atomic force modulation microscopy. IAWA J 24:223-230 
Clair B, Jaouen G, Beauchêne J, Fournier M (2003b) Mapping radial, tangential and longitudinal shrinkages and relation to tension wood in discs of the tropical tree Symphonia globulifera. Holzforschung 57:665-671

Clair B, Ruelle J, Thibaut B (2003c) Relationship between growth stress, mechano-physical properties and proportion of fibre with gelatinous layer in chestnut (Castanea sativa Mill.). Holzforschung 57:189-195

Clair B, Gril J, Baba K, Sugiyama J (2004) Revealing growth stresses at the cell-wall level in poplar tension wood. In: Morlier P, Morais J, Dourado N (eds) Third international conference of the European society for wood mechanics. UTAD, Vila Real, pp 175-181

Clair B, Thibaut B, Sugiyama J (2005a) On the detachment of gelatinous layer in tension wood fiber. J Wood Sci 51:218-221

Clair B, Gril J, Baba K, Thibaut B, Sugiyama J (2005b) Precautions for the structural analysis of the gelatinous layer in tension wood. IAWA J 26:189-195

Clair B, Alméras T, Yamamoto H, Okuyama T, Sugiyama J (2006a) Mechanical behavior of cellulose microfibrils in tension wood, in relation with maturation stress generation. Biophys $\mathrm{J}$ 91:1128-1135

Clair B, Ruelle J, Beauchêne J, Prévost M-F, Fournier Djimbi M (2006b) Tension wood and opposite wood in 21 tropical rain forest species. 1. Occurrence and efficiency of the G-layer. IAWA J 27:329-338

Clair B, Gril J, Di Renzo F, Yamamoto H, Quignard F (2008) Characterization of a gel in the cell wall to elucidate the paradoxical shrinkage of tension wood. Biomacromolecules 9:494-498

Clarke SH (1937) The distribution, structure and properties of tension wood in beech (Fagus silvatica L.). Forestry 11:85-91

Coutand C, Jeronimidis G, Chanson B, Loup C (2004) Comparison of mechanical properties of tension and opposite wood in Populus. Wood Sci Technol 38:11-24

Dadswell HE, Wardrop AB (1955) The structure and properties of tension wood. Holzforschung 9:97-104

Dinh AT, Pilate G, Assor C, Perré P (2008) Measurement of the elastic properties of minute samples of wood along the three material directions. COST Action IE0601/ESWM, Braga, $6 \mathrm{pp}$

Fang C-H, Clair B, Gril J, Alméras T (2007) Transverse shrinkage in G-fibers as a function of cell wall layering and growth strain. Wood Sci Technol 41:659-671

Fang C-H, Guibal D, Clair B, Gril J, Lu Y-M, Liu S-Q (2008a) Relationships between growth stress and wood properties in poplar I-69 (Populus deltoides Bartr. cv. "Lux" ex I-69/55). Ann Forest Sci 65:307 (9 pp)

Fang C-H, Clair B, Gril J, Liu S-Q (2008b) Growth stresses are highly controlled by the amount of G-layer in poplar tension wood. IAWA J 29:237-246

Fisher JB, Stevenson JW (1981) Occurrence of reaction wood in branches of dicotyledons and its role in tree architecture. Bot Gazette 142:82-95

Gindl W (2002) Comparing mechanical properties of normal and compression wood in Norway spruce: the role of lignin in compression parallel to the grain. Holzforschung 56:395-401

Gindl W, Teischinger A (2003) Comparison of the TL-shear strength of normal and compression wood of European larch. Holzforschung 57:421-426

Gindl W, Teischinger A, Schwanninger M, Hinterstoisser B (2001) The relationship between near infrared spectra of radial wood surfaces and wood mechanical properties. J Near Infrared Spectrosc 9:255-261

Gindl W, Gupta HS, Schöberl T, Lichtenegger HC, Fratzl P (2004) Mechanical properties of spruce wood cell walls by nanoindentation. Appl Phys A Mater Sci Process 79:2069-2073

Gril J, Berrada E, Thibaut B (1993) Recouvrance hygrothermique du bois vert. Il. Variations dans le plan transverse chez le châtaignier et l'épicéa et modélisation de la fissuration à coeur provoquée par l'étuvage. Ann Sci For 50:487-508 
Gril J, Sassus F, Yamamoto H, Guitard D (1999) Maturation and drying strain of wood in longitudinal direction: a single-fibre mechanical model. In: Nepveu G (ed) 3rd workshop on connection between silviculture and wood quality through modelling approaches and simulation softwares (IUFRO WP S5.01.04 "Biological Improvement of Wood Properties"). ERQBINRA Nancy, La Londe-Les-Maures, 309-313

Grzeskowiak V, Sassus F, Fournier M (1996) Coloration macroscopique, retraits longitudinaux de maturation et de séchage du bois de tension du peuplier (Populus x euramericana cv 1.214). Ann Sci For 53:1083-1097

Harrington JJ, Booker RE, Astley RJ (1998) Modelling the elastic properties of softwood. Part I: the cell-wall lamellae. Holz Roh Werkst 56:37-41

Hayashi T, Kaida R (2010) Functions of xyloglucan in plant cells. Mol Plant 4:17-24. doi:10.1093/ $\mathrm{mp} / \mathrm{ssq} 063$

Ikushima T, Soga K, Hoson T, Shimmen T (2008) Role of xyloglucan in gravitropic bending of azuki bean epicotyl. Physiol Plant 132:552-565

Jourez B, Riboux A, Leclercq A (2001a) Comparison of basic density and longitudinal shrinkage in tension wood and opposite wood in young stems of Populus euramericana cv. Ghoy when subjected to a gravitational stimulus. Can J For Res 31:1676-1683

Jourez B, Riboux A, Leclercq A (2001b) Anatomical characteristics of tension wood and opposite wood in young inclined stems of poplar (Populus euramericana CV "Ghoy"). IAWA J 22:133-157

Jullien D, Gril J (2003) Modelling crack propagation due to growth stress release in round wood. J Phys IV 105:265-272

Kaku T, Serada S, Baba K, Tanaka F, Hayashi T (2009) Proteomic analysis of the G-layer in poplar tension wood. J Wood Sci 55:250-257

Konnerth J, Gindl W (2006) Mechanical characterisation of wood-adhesive interphase cell walls by nanoindentation. Holzforschung 60:429-433

Koponen S, Toratti T, Kanerva P (1989) Modelling longitudinal elastic and shrinkage properties of wood. Wood Sci Technol 23:55-63

Koponen S, Toratti T, Kanerva P (1991) Modelling elastic and shrinkage properties of wood based on cell structure. Wood Sci Technol 25:25-32

Kroll RE, Ritter DC, Au KC (1992) Anatomical and physical properties of balsam poplar (Populus balsamifera L.) in Minnesota. Wood Fiber Sci 24:13-24

Kubler H (1987) Growth stresses in trees and related wood properties. For Prod Abstr 10:62-119

Lafarguette F, Leplé J-C, Déjardin A, Laurans F, Costa G, Lesage-Descauses M-C (2004) Poplar genes encoding fasciclin-like arabinogalactan proteins are highly expressed in tension wood. New Phytol 164:107-121

Lowell EC, Krahmer RL (1993) Effects of lean in red alder trees on wood shrinkage and density. Wood Fiber Sci 25:2-7

Mark RE (1973) The relationship between fiber modulus and S2 angle. Tappi 56:164-167

McLean JP, Arnould O, Beauchêne J, Clair B (2012) The effect of the G-layer on the viscoelastic properties of tropical hardwoods. Ann For Sci 69:399-408

Mellerowicz EJ, Immerzeel P, Hayashi T (2008) Xyloglucan: the molecular muscle of trees. Ann Bot 102:659-665

Metzger K (1908) Über das Konstruktionsprinzip des sekundären Holzkörpers. Naturwiss Zeitschr Forst Landwirtschaft 6:249-273

Nishikubo N, Awano T, Banasiak A, Bourquin V, Ibatullin F, Funada R, Brumer H, Teeri TT, Hayashi T, Sundberg B, Mellerowicz EJ (2007) Xyloglucan endo-transglycosylase (XET) functions in gelatinous layers of tension wood fibers in poplar-a glimpse into the mechanism of the balancing act of trees. Plant Cell Physiol 48:843-855

Norberg H, Meier H (1966) Physical and chemical properties of the gelatinous layer in tension wood fibres of aspen (Populus tremula L.). Holzforschung 20:174-178

Onaka F (1949) Studies on compression and tension wood. Wood Res Bull Wood Res Inst Kyoto Univ 1:1-88 
Ono T, Norimoto M (1983) Study on Young's modulus and internal friction of wood in relation to the evaluation of wood for musical instruments. Jpn J Appl Phys 22:611-614

Passard J, Perré P (2005) Viscoelastic behaviour of green wood across the grain. Part II. A temperature dependent constitutive model defined by inverse method. Ann For Sci 62:823-830

Pillow MY (1956) Presence of tension wood in mahogany in relation to longitudinal shrinkage. Report US Forest Product Laboratory $n^{\circ} \mathrm{D} 1763$

Placet V, Passard J, Perré P (2007) Viscoelastic properties of green wood across the grain measured by harmonic tests in the range $0-95^{\circ} \mathrm{C}$ : hardwood vs. softwood and normal wood vs. reaction wood. Holzforschung 61:548-557

Potter MC (1924) On the occurrence of cellulose in the xylem of woody stems. Ann Bot 18:121-140

Reiterer A, Lichtenegger H, Tschegg S, Fratzl P (1999) Experimental evidence for a mechanical function of the cellulose microfibril angle in wood cell wall. Philos Mag A 79:2173-2184

Ruelle J, Clair B, Beauchêne J, Prévost M-F, Fournier M (2006) Tension wood and opposite wood in 21 tropical rain forest species. 2. Comparison of some anatomical and ultrastructural criteria. IAWA J 27:341-376

Ruelle J, Beauchêne J, Thibaut A, Thibaut B (2007a) Comparison of physical and mechanical properties of tension and opposite wood from ten tropical rainforest trees from different species. Ann For Sci 64:503-510

Ruelle J, Yamamoto H, Thibaut B (2007b) Growth stresses and cellulose structural parameters in tension and normal wood from three tropical rainforest angiosperm species. Bioresources 2:235-251

Ruelle J, Beauchêne J, Yamamoto H, Thibaut B (2011) Variations in physical and mechanical properties between tension and opposite wood from three tropical rainforest species. Wood Sci Technol 45:339-357

Sachsse H (1965) Untersuchungen über den Einfluss der Ästung auf die Farbkern- und Zugholzausbildung einiger Pappelsorten. Holz Roh Werkst 23:425-434

Salmén L (2004) Micromechanical understanding of the cell-wall structure. Comp Rend Biol 327:873-880

Salmén L, de Ruvo A (1985) A model for the prediction of fiber elasticity. Wood Fiber Sci $17: 336-350$

Salmén L, Burgert I (2009) Cell wall features with regard to mechanical performance. A review selected articles from the COST action E35: wood machining micromechanics and fracture. Holzforschung 63:121-129

Sanio C (1860a) Einige Bemerkungen über den Bau des Holzes - I. Ueber den Bau des Tÿpfels und Hofes. Botanische Zeitung 18:193-200

Sanio C (1860b) Einige Bemerkungen über den Bau des Holzes - II. Ueber dee tertiäre verdickungsschicht der holzzellen. Botanische Zeitung 18:201-204

Sanio C (1863) Vergleichende Untersuchungen über die elementarorgane des Holzkörpers. II. Bastfaserähnliches system. Botanische Zeitung 21:101-111

Terrell B (1953) Distribution of tension wood and its relation to longitudinal shrinkage in aspen. Plant Foods for Human Nutrition (Formerly Qualitas Plantarum)

Timell TE (1986) Compression wood in gymnosperms. 1. Bibliography, historical background, determination, structure, chemistry, topochemistry, physical properties, origin, and formation of compression wood. Springer, Berlin, p 2150

Wardrop AB, Dadswell HE (1948) The nature of reaction wood. I. The structure and properties of tension wood fibres. Aust J Sci Res Ser B Biol Sci 1:3-16

Wardrop AB, Dadswell HE (1955) The nature of reaction wood. IV. Variations in cell wall organization of tension wood fibres. Aust J Bot 3:177-189

Washusen R, Evans R (2001) Prediction of wood tangential shrinkage from cellulose crystallite width and density in one 11-year-old tree of Eucalyptus globulus Labill. Aust For 64:123-126

Washusen R, Ilic J (2001) Relationship between transverse shrinkage and tension wood from three provenances of Eucalyptus globulus Labill. Holz Roh Werkst 59:85-93 
Washusen R, Ades P, Evans R, Ilic J, Vinden P (2001) Relationships between density, shrinkage, extractives content and microfibril angle in tension wood from three provenancesof 10-yearold Eucalyptus globulus Labill. Holzforschung 55:176-182

Yamamoto H (1999) A model of anisotropic swelling and shrinking process of wood. Part 1. Generalization of Barber's wood fiber model. Wood Sci Technol 33:311-325

Yamamoto H, Abe K, Arakawa Y, Okuyama T, Gril J (2005) Role of the gelatinous layer (G-layer) on the origin of the physical properties of the tension wood of Acer sieboldianum. J Wood Sci $51: 222-233$

Yamamoto H, Ruelle J, Arakawa Y, Yoshida M, Clair B, Gril J (2009) Origin of the characteristic hygro-mechanical properties of the gelatinous layer in tension wood from kunugi oak (Quercus acutissima). Wood Sci Technol 44:149-163. doi:10.1007/s00226-009-0262-5

Yang JL, Evans R (2003) Prediction of MOE of eucalypt wood from microfibril angle and density. Holz Roh Werkst 61:449-452

Yang JL, Ilic J (2003) A new method of determining growth stress and relationships between associated wood properties of Eucalyptus globulus Labill. Aust For 66:153-157 